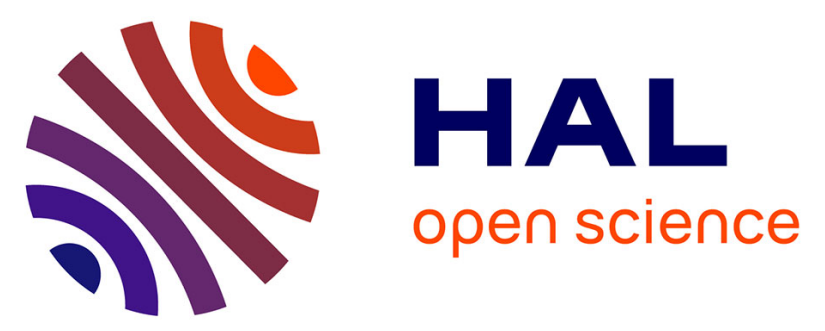

\title{
Supporting evidence from the EPICA Dronning Maud Land ice core for atmospheric CO2 changes during the past millennium
}

\author{
Urs Siegenthaler, Eric Monnin, Kenji Kawamura, Renato Spahni, Jakob \\ Schwander, Bernard Stauffer, Thomas F. Stocker, Jean-Marc Barnola, \\ Hubertus Fischer
}

\section{To cite this version:}

Urs Siegenthaler, Eric Monnin, Kenji Kawamura, Renato Spahni, Jakob Schwander, et al.. Supporting evidence from the EPICA Dronning Maud Land ice core for atmospheric CO2 changes during the past millennium. Tellus B - Chemical and Physical Meteorology, 2005, 57 (1), pp.51 à 57. 10.1111/j.16000889.2005.00131.x . insu-00374931

\section{HAL Id: insu-00374931 \\ https://hal-insu.archives-ouvertes.fr/insu-00374931}

Submitted on 22 Jun 2021

HAL is a multi-disciplinary open access archive for the deposit and dissemination of scientific research documents, whether they are published or not. The documents may come from teaching and research institutions in France or abroad, or from public or private research centers.
L'archive ouverte pluridisciplinaire HAL, est destinée au dépôt et à la diffusion de documents scientifiques de niveau recherche, publiés ou non, émanant des établissements d'enseignement et de recherche français ou étrangers, des laboratoires publics ou privés. 


\title{
Supporting evidence from the EPICA Dronning Maud Land ice core for atmospheric $\mathrm{CO}_{2}$ changes during the past millennium
}

\author{
Urs Siegenthaler, Eric Monnin, Kenji Kawamura, Renato Spahni, Jakob \\ Schwander, Bernhard Stauffer, Thomas F. Stocker, Jean-Marc Barnola \& \\ Hubertus Fischer
}

To cite this article: Urs Siegenthaler, Eric Monnin, Kenji Kawamura, Renato Spahni, Jakob Schwander, Bernhard Stauffer, Thomas F. Stocker, Jean-Marc Barnola \& Hubertus Fischer (2005) Supporting evidence from the EPICA Dronning Maud Land ice core for atmospheric $\mathrm{CO}_{2}$ changes during the past millennium, Tellus B: Chemical and Physical Meteorology, 57:1, 51-57, DOI: 10.3402/tellusb.v57i1.16774

To link to this article: https://doi.org/10.3402/tellusb.v57i1.16774

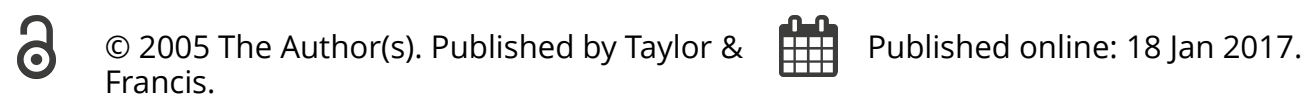

Submit your article to this journal $₫ \quad$ Џ Article views: 250 


\title{
Supporting evidence from the EPICA Dronning Maud Land ice core for atmospheric $\mathrm{CO}_{2}$ changes during the past millennium
}

\author{
By URS SIEGENTHALER ${ }^{1 *}$, ERIC MONNIN ${ }^{1}$, KENJI KAWAMURA ${ }^{1}$, RENATO SPAHNI ${ }^{1}$, \\ JAKOB SCHWANDER ${ }^{1}$, BERNHARD STAUFFER ${ }^{1}$, THOMAS F. STOCKER ${ }^{1}$, JEAN-MARC \\ BARNOLA ${ }^{2}$ and HUBERTUS FISCHER ${ }^{3},{ }^{1}$ Climate and Environmental Physics, Physics Institute, \\ University of Bern, Bern, Switzerland; ${ }^{2}$ CNRS Laboratoire de Glaciologie et de Géophysique de l'Environnement \\ (LGGE), Grenoble, France; ${ }^{3}$ Alfred Wegener Institut für Polar- und Meeresforschung, Bremerhaven, Germany
}

(Manuscript received 17 January 2004; in final form 5 August 2004)

\begin{abstract}
The most direct method of investigating past variations of the atmospheric $\mathrm{CO}_{2}$ concentration before 1958 , when continuous direct atmospheric $\mathrm{CO}_{2}$ measurements started, is the analysis of air extracted from suitable ice cores. Here we present a new detailed $\mathrm{CO}_{2}$ record from the Dronning Maud Land (DML) ice core, drilled in the framework of the European Project for Ice Coring in Antarctica (EPICA) and some new measurements on a previously drilled ice core from the South Pole. The $\mathrm{DML} \mathrm{CO}_{2}$ record shows an increase from about 278 to 282 parts per million by volume (ppmv) between AD 1000 and AD 1200 and a fairly continuous decrease to a mean value of about 277 ppmv around AD 1700 . While the new South Pole measurements agree well with DML at the minimum at AD 1700 they are on average about 2 ppmv lower during the period AD 1000-1500. Published measurements from the coastal high-accumulation site Law Dome are considered as very reliable because of the reproducibility of the measurements, high temporal resolution and an accurate time scale. Other Antarctic ice cores could not, or only partly, reproduce the pre-industrial measurements from Law Dome. A comparison of the trends of DML and Law Dome shows a general agreement. However we should be able to rule out co-variations caused by the same artefact. Two possible effects are discussed, first production of $\mathrm{CO}_{2}$ by chemical reactions and second diffusion of dissolved air through the ice matrix into the bubbles. While the first effect cannot be totally excluded, comparison of the Law Dome and DML record shows that dissolved air diffusing to bubbles cannot be responsible for the pre-industrial variation. Therefore, the new record is not a proof of the Law Dome results but the first very strong support from an ice core of the Antarctic plateau.
\end{abstract}

\section{Introduction}

$\mathrm{CO}_{2}$ measurements of recent air extracted from ice cores (Neftel et al., 1985; Etheridge et al., 1996) overlap with direct atmospheric measurements (Keeling and Whorf, 2003) and are in good agreement, clearly confirming the reliability of the recent ice core $\mathrm{CO}_{2}$ record. Records from Antarctic ice cores show a mean value of about 280 parts per million by volume (ppmv) for the last millennium before the anthropogenic increase started (Barnola, 1999). However, variations between 5 and 10 ppmv are observed in the pre-industrial epoch in Antarctic records from Siegenthaler et al. (1988), Barnola et al. (1995) and Etheridge et al. (1996). These variations, which are important for the understanding of the global carbon cycle, are significant con-

${ }^{*}$ Corresponding author.

e-mail: siegenthaler@climate.unibe.ch sidering the analytical uncertainties, but the time evolution of these records is quite different. A record from Central Greenland (Barnola et al., 1995) shows $\mathrm{CO}_{2}$ concentrations of 283.0 \pm 2.4 ppmv for the period AD 1600-1800 and 289.9 $\pm 2.9 \mathrm{ppmv}$ between $\mathrm{AD} 1000$ and 1600 . These values are significantly higher than the ones from Law Dome $(277.9 \pm 2.0 \mathrm{ppmv}$ and $281.6 \pm$ $1.4 \mathrm{ppmv}$, respectively) and in view of in situ production of $\mathrm{CO}_{2}$ in Greenland ice (Anklin et al., 1995; Smith et al., 1997) are not considered to represent the atmospheric $\mathrm{CO}_{2}$ concentration. Ice cores from Antarctic high-plateau drill sites, generally exhibiting very low surface temperatures and low impurity concentrations, are better suited for reliable $\mathrm{CO}_{2}$ measurements. However, the temperature at Law Dome is $10{ }^{\circ} \mathrm{C}$ higher than at Summit and the impurity concentrations of $\mathrm{Ca}^{2+}$ and $\mathrm{H}_{2} \mathrm{O}_{2}$, which are connected to in situ $\mathrm{CO}_{2}$ production are about one-half of those at Summit (Table 1). Accordingly, significant atmospheric $\mathrm{CO}_{2}$ changes as recorded in the Law Dome ice core during the 
Table 1. Details of the ice cores used in this study

\begin{tabular}{|c|c|c|c|c|c|c|c|}
\hline Ice core & Location & $\begin{array}{l}\text { Accumulation } \\
\text { rate } \\
\left(\mathrm{kg} \mathrm{m}^{-2} \mathrm{yr}^{-1}\right)\end{array}$ & $\begin{array}{c}\text { Mean } \\
\text { temperature } \\
\left({ }^{\circ} \mathrm{C}\right)\end{array}$ & $\begin{array}{l}\text { Delta age } \\
(\mathrm{yr})\end{array}$ & $\begin{array}{c}\text { Age distribution } \\
\text { width at half height } \\
(\mathrm{yr})\end{array}$ & $\begin{array}{l}\mathrm{H}_{2} \mathrm{O}_{2} \\
\text { (ppbw) }\end{array}$ & $\begin{array}{c}\mathrm{Ca}^{2+} \\
(\mathrm{ppbw})\end{array}$ \\
\hline DML & $75^{\circ} 00^{\prime} \mathrm{S}, 00^{\circ} 04^{\prime} \mathrm{E}$ & 64 & -44.6 & 825 & $59 \pm 5$ & $10.1^{\mathrm{a}}$ & $1.3^{\mathrm{a}}$ \\
\hline South Pole & $90^{\circ} \mathrm{S}$ & 76.2 & -51 & 950 & $95 \pm 5$ & $11.6 / 16.7^{b}$ & \\
\hline DSS Law Dome & $66^{\circ} 46^{\prime} \mathrm{S}, 112^{\circ} 48^{\prime} \mathrm{E}$ & 600 & -22 & 58 & & $34 / 41^{c}$ & $3.6^{\mathrm{d}}$ \\
\hline Summit (GRIP) & $72^{\circ} 34^{\prime} \mathrm{N}, 37^{\circ} 37^{\prime} \mathrm{W}$ & 200 & -32 & 210 & & $72.6^{\mathrm{e}}$ & $8.1^{\mathrm{e}}$ \\
\hline
\end{tabular}

${ }^{a}$ Mean value of the continuous measurements on the B32 core covering the gas age period of AD 1300-1900. (Sommer, 2000).

${ }^{b}$ Measurements in a depth attributed to an age in the gas age scale used in this work of AD 1369 and AD 975 (Neftel et al., 1984).

${ }^{\mathrm{c}}$ Mean value of samples with a mean age of AD 1648 and AD 1541 (Gillet et al., 2000).

${ }^{\mathrm{d}}$ Mean value of continuous measurements covering the period of AD 1301-1997 (Mark Curran, personal communication).

${ }^{\mathrm{e}}$ Mean value of continuous measurements covering the period of 9000-7800 BP (Fuhrer et al., 1993).

last millennium (Etheridge et al., 1996) require an independent confirmation from high-altitude Antarctic sites. In addition the reason for the difference in Greenland and Antarctic ice core $\mathrm{CO}_{2}$ records over the last millennium has not been ultimately resolved.

In this paper we present new $\mathrm{CO}_{2}$ data derived from the EPICA (European Project for Ice coring in Antarctica) ice core currently being drilled in Dronning Maud Land (DML) as well as additional measurements on the South Pole ice core and compare those with the high-resolution Law Dome $\mathrm{CO}_{2}$ record. In addition, we try to quantify potential artefacts which may be responsible for intersite differences in $\mathrm{CO}_{2}$ concentrations. Those processes are chemical reactions within the ice as well as diffusion of high $\mathrm{CO}_{2}$ trapped in microbubbles in the ice during snow formation into larger air bubbles, both processes having different magnitudes and rates due to different rates of snow accumulation, temperature and impurity content.

\section{Methods}

Generally, a dry extraction method is used where samples of 6-8 $g$ are crushed by a needle cracker. The partial pressure of $\mathrm{CO}_{2}$ is measured using infrared laser spectrometry (IRLS). The analytical uncertainty of standard gas introduced over bubblefree ice was 1.7 ppmv during the measurements on the DML core. More detailed information about the analytical method is given in Indermühle et al. (1999). We measured samples covering the time period from $\mathrm{AD} 950$ to $\mathrm{AD} 1900$ on 71 and 14 depth intervals of the DML and the South Pole ice core, respectively. At each depth interval of $60-100 \mathrm{~mm}$, six samples were measured. Figure 1 shows the arithmetic means of six samples for each depth interval with a standard error of the mean in the range of 0.5-2.5 ppmv as error bars.

The DML and South Pole data are corrected for gravitational separation of gases in the firn column based on the barometric formula to get closer to the true atmospheric value. The closeoff depths are calculated with the same model as in Barnola

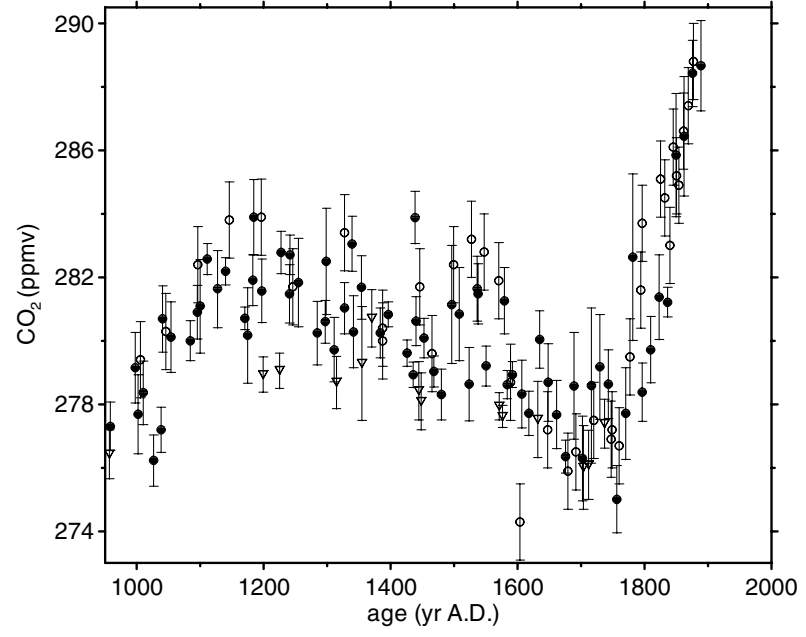

Fig 1. Full circles: $\mathrm{CO}_{2}$ data from DML. Open triangles: New measurements on the South Pole ice core. Both records were measured with dry extraction (mean of six samples; error bars, $1 \sigma$ of the mean). Open circles: Law Dome data (Etheridge et al., 1996).

et al. (1991) with the close-off densities calculated according to Martinerie et al. (1994) (834 and $837 \mathrm{~kg} \mathrm{~m}^{-3}$ for DML and South Pole, respectively). For a concentration of $280 \mathrm{ppmv}$, the gravitational correction for DML and the South Pole is 1.9 and 2.6 ppmv, respectively.

No published timescale is available yet for the DML ice core. We construct a tentative timescale by adjusting the DML timescale to Dome $\mathrm{C}$ by comparing the records of electrical conductivity for both cores. The difference of gas age/ice age was assumed as $825 \mathrm{yr}$.

\section{Results}

The DML $\mathrm{CO}_{2}$ record shows an increase from about 278 to 282 ppmv between $\mathrm{AD} 1000$ and $\mathrm{AD} 1200$ and a fairly continuous decrease to a mean value of about 277 ppmv around AD 1700 
(Fig. 1). Variations of the atmospheric $\mathrm{CO}_{2}$ concentrations on a centennial timescale were suggested many years ago based on measurements along the South Pole ice core (Siegenthaler et al., 1988). We remeasured samples from this core for 14 depth levels. The results are shown in Fig. 1. A new timescale was calculated, because an event recorded with the electrical conductivity method (ECM) attributed to a volcanic eruption in AD 1259 (Langway et al., 1988) indicates that the timescale used in Siegenthaler et al. (1988) is too young at this depth. This results in a lower average accumulation rate of $76.2 \mathrm{~kg} \mathrm{~m}^{-2} \mathrm{yr}^{-1}$ compared with the previously used value of $84 \mathrm{~kg} \mathrm{~m}^{-2} \mathrm{yr}^{-1}$. On average, the South Pole scale was about $200 \mathrm{yr}$ too young over the last millennium. The new South Pole data follow the lower envelope of the data published in 1988 (not shown) and, similar to the DML results, also show a fairly continuous decrease between $\mathrm{AD} 1200$ to a minimum concentration around $\mathrm{AD} 1700$. While this minimum agrees well with DML, the South Pole data are on average about 2 ppmv lower than the DML record in the first half of the millennium. The most evident difference is at about AD 1200, where two South Pole measurements are 3 ppmv lower than the trend of the DML record. Therefore, the decrease from AD 1200-1700 seems to be less pronounced in the South Pole record.

The record from Law Dome (Etheridge et al., 1996) is considered as very reliable because of the reproducibility of the measurements of $1.2 \mathrm{ppmv}$ and the high accumulation rate of $600 \mathrm{~kg} \mathrm{~m}^{-2} \mathrm{yr}^{-1}$ at Law Dome leading to a higher temporal resolution and a smaller error in the ice age/gas age difference. For the DML and South Pole sites, the observed accumulation rates are about nine and eight times lower, respectively. Low accumulation rates cause an attenuation of fast variations in atmospheric $\mathrm{CO}_{2}$ concentration which has to be taken into account. Processes for the attenuation are molecular diffusion in the open pores of the firn column and the gradual bubble close-off in the depth of the transition from firn to ice. The lower the accumulation rate, the wider is the age distribution of the enclosed air. The model by Spahni et al. (2003), which takes both molecular diffusion and gradual bubble close-off into account, has been used to determine the attenuation. An adjustment with the density profile and estimates of today's firn parameters in the model results in an air age distribution with a width at half height of 59 and $95 \mathrm{yr}$ for the DML and South Pole cores, respectively. We use these age distributions for comparison of the new results with data from the high-accumulation site at Law Dome. To this end we smoothed the Law Dome data with the modelled age distribution of DML and the South Pole (Fig. 2).

The most evident difference between DML and Law Dome is in the period AD 1000-1500 where the Law Dome values are higher by about $0.5-2.5$ ppmv. Although the decrease at about $\mathrm{AD} 1600$ seems to be less pronounced because of lower values at about $\mathrm{AD} 1550$ in the $\mathrm{DML}$ core, the remarkable minimum between $\mathrm{AD} 1600$ and $\mathrm{AD}$ 1750, which was questioned by Stauffer et al. (2002), could apparently be confirmed.

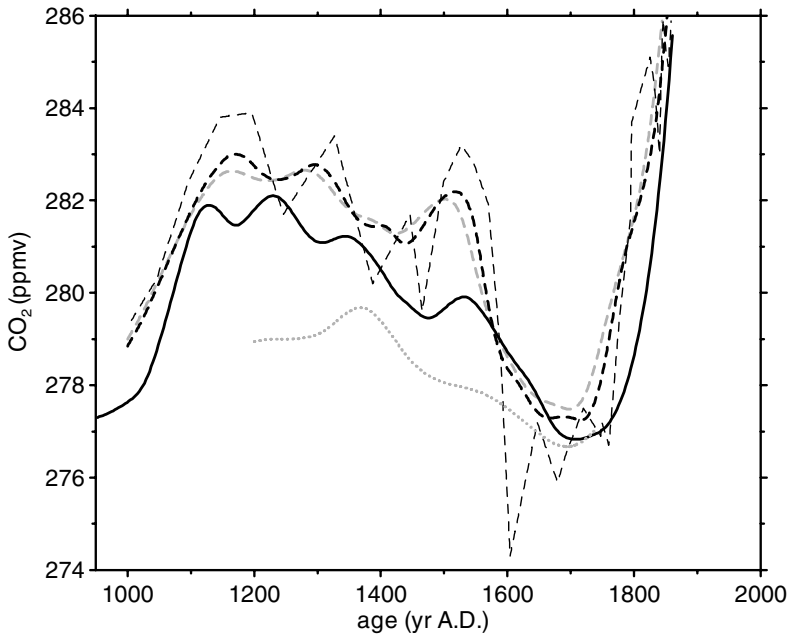

Fig 2. Dashed thin curve: interpolated Law Dome data (Etheridge et al., 1996). Dashed thick and grey curves: signal of Law Dome as it would be smoothed in the ice cores from DML and the South Pole, respectively. The signal is calculated for both cores using the modelled age distribution after Spahni et al. (2003). Full black and dotted grey curves: spline with a cut-off period of $200 \mathrm{yr}$ of the DML and South Pole data, respectively.

\section{Discussion}

The atmospheric $\mathrm{CO}_{2}$ evolution recorded in the DML record confirms, within the uncertainties of the measurements and the air age resolution, the findings from the Law Dome record. It was speculated that the distinct minimum at about $\mathrm{AD} 1700$ is related to the Little Ice Age. However, it would be very surprising if this climatic event, which is ubiquitous in the North Atlantic region but not well-defined temporally and of rather small temperature anomalies, would have such a distinct effect on $\mathrm{CO}_{2}$. Another feature observed in the $\mathrm{CO}_{2}$ data is difficult to explain. The model of Gerber et al. (2003), forced by the reconstructed variability in solar irradiance and radiative forcing by volcanoes, simulated a fairly continuous decrease of atmospheric $\mathrm{CO}_{2}$ between $\mathrm{AD} 1200$ and $\mathrm{AD} 1800$, but the measured increase between $\mathrm{AD}$ 1000 and $\mathrm{AD} 1200$ was not reproduced by the model.

Knowledge of the palaeoatmospheric carbon dioxide concentration is a key for a better understanding of the global carbon cycle. Therefore it has to be carefully checked if the good agreement of the records from DML and Law Dome could not be affected by the same artefact, despite different characteristics of the drilling sites.

Two possibilities for such artefacts are:

- $\mathrm{CO}_{2}$ is produced by chemical reactions between impurities in the ice. The reactions need centuries to approach an equilibrium and do therefore not affect very young ice.

- $\mathrm{CO}_{2}$ originally dissolved or enclosed as microbubbles in firn grains is not extracted in young ice by a dry extraction 
method. In older ice the dissolved $\mathrm{CO}_{2}$ will diffuse to the bubbles and will be extracted by dry extraction.

Both artefacts would not influence the good agreement of $\mathrm{CO}_{2}$ records from ice cores with direct atmospheric measurements in the overlapping period.

$\mathrm{CO}_{2}$ can be produced in the ice by acid-carbonate reactions or the oxidation of organic material (Tschumi and Stauffer, 2000). This production will certainly depend on the concentration of impurities (carbonates, acidic compounds, dissolved organic compounds, oxidation agents such as $\mathrm{H}_{2} \mathrm{O}_{2}$ ) and it will need a certain time to appear. It was observed that reaction compounds are still present after thousands of years in ice cores. One or several of the original reaction compounds can be concentrated in dust grains, in grain boundaries or in veins, or formed along the edges where three ice crystals meet. Tschumi and Stauffer (2000) suggest that the reaction rate is that low because it depends on the probability that molecules from each source compound will come close enough to react. The produced $\mathrm{CO}_{2}$ will occur, like the dissolved $\mathrm{CO}_{2}$ from microbubbles, somewhere within the ice matrix and has to diffuse to air bubbles to be extracted by a dry extraction method. Therefore, any dry extraction method would measure such surplus $\mathrm{CO}_{2}$ with a delay which depends mainly on the temperature of the ice.

The concentrations of impurities in the coastal Law Dome ice (Gillet et al., 2000; Souney et al., 2002) are higher than in the ice of DML on the Antarctic Plateau (Sommer, 2000). Concentrations of $\mathrm{Ca}^{2+}$ (a proxy for carbonate concentration) and of the oxidation agent $\mathrm{H}_{2} \mathrm{O}_{2}$ are shown in Table 1 .

However, if $\mathrm{CO}_{2}$ produced by chemical reactions were responsible for the values above 276 ppmv before $\mathrm{AD} 1700$ then it would be difficult to explain why the concentration would be low for all three records at the beginning of the millennium again.

Can we, based on these considerations, exclude any artefacts? Not necessarily - there is an additional observation which is puzzling. High-resolution records over short time intervals from the Dome $\mathrm{C}$ and DML record show a significantly higher scatter of $\mathrm{CO}_{2}$ measurements for young ice (last millennium) than for older ice. This scatter is slightly higher than the analytical uncertainty, indicating the existence of some artefacts caused by processes in the ice sheet or during the extraction procedure. However, it is unlikely that the mean deviations exceed $1 \%$ of the measured concentration (Stauffer et al., 2003). In summary an explanation of variations or intersite differences in the three records based on in situ chemical production of $\mathrm{CO}_{2}$ does not seem to be straightforward.

To quantify the effect of microbubbles we additionally performed extraction of air from ice cores with a sublimation method which allows us to also extract the $\mathrm{CO}_{2}$ dissolved in the ice. Sublimation takes place below the triple point of water, which avoids dissolving $\mathrm{CO}_{2}$ and a potential production of $\mathrm{CO}_{2}$ by acid-carbonate reactions in the liquid phase (Stauffer and Berner, 1978). Furthermore, extraction by sublimation avoids fraction- ation effects, because the extraction efficiency is close to $100 \%$ and independent of whether air is enclosed in bubbles, clathrates or dissolved in the ice.

The sublimation device, used at our laboratory for tests and not for routine measurements, is similar to the one of Güllük et al. (1998). Tests of the sublimation extraction were performed with bubble-free ice and the addition of standard gas. Tests during the time period of the DML measurements showed a reproducibility of $1.5 \mathrm{ppmv}$ with a mean concentration which was 0.1 ppmv below the concentration of the standard gas. The eight measurements on the DML ice core during the time period AD 1000-1800 obtained with the sublimation method (not shown) are on average $1.0 \mathrm{ppmv}$ higher than the results obtained with the dry extraction. Unfortunately, the sublimation results show a surprisingly large scatter (about 3 ppmv) and therefore a larger uncertainty than in the tests with bubble-free ice. However, the agreement of the two extraction methods allows the conclusion that a fractionation effect for the dry extraction of more than 5 ppmv is unlikely in the measured DML ice. But the results unfortunately do not allow us to confirm or disprove the hypothesis of dissolved $\mathrm{CO}_{2}$ in young ice causing a fractionation effect of the order of a few ppmv.

Therefore, we try to quantify this effect using a simple diffusion model. The $\mathrm{CO}_{2}$ content enclosed or dissolved in the firn is enriched compared with the air enclosed in bubbles after the firn-ice transition. Measurements with a wet extraction on evacuated firn samples from the North Central ice core $\left(74^{\circ} 37^{\prime} \mathrm{N}\right.$, $39^{\circ} 36^{\prime} \mathrm{W}, T=-31.7^{\circ} \mathrm{C}$ ) showed that especially the first $10 \mathrm{~m}$ of the firn core were enriched in $\mathrm{CO}_{2}$ by more than $10000 \mathrm{ppmv}$ (Stauffer, 1981). While wet extraction of $\mathrm{CO}_{2}$ is prone to acidcarbonate reactions, another hypothesis is that highly enriched $\mathrm{CO}_{2}$ is enclosed in microbubbles, which would not be opened by a classical dry extraction method.

The question arises of how fast this possibly high level of $\mathrm{CO}_{2}$ permeates through the ice matrix into the normal air bubbles and therefore influences the measured $\mathrm{CO}_{2}$ concentration. In the Vostok ice core, it was observed that the volume fraction of microbubbles with respect to all bubbles is $0.3 \%$ (Lipenkov, $2000)$. For an estimate we assume that $0.5 \%$ of the total air content (100 $\mathrm{ml}$ air STP per $\mathrm{kg}$ ice) is enclosed in microbubbles. The composition of air in the normal bubbles is assumed to be atmospheric with a $\mathrm{CO}_{2}$ concentration of 275 ppmv. The composition of the air in the microbubbles is certainly enriched in more soluble components. The partial pressure of $\mathrm{CO}_{2}$ in air dissolved in water of $0{ }^{\circ} \mathrm{C}$ in equilibrium with an atmosphere of 275 ppmv is greater than 15000 ppmv. A large part of the enriched air may escape through the open pores of the firn. Because of the growth of firn grains by sublimation-condensation, most of the microbubbles have contact with the firn grain boundaries. Using the parametrization of Gow (1969) for the firn grain growth, the fraction of microbubbles that have never had contact with grain boundaries in the firn zone, where the escape of enriched air through the open pores might be possible, is in the 


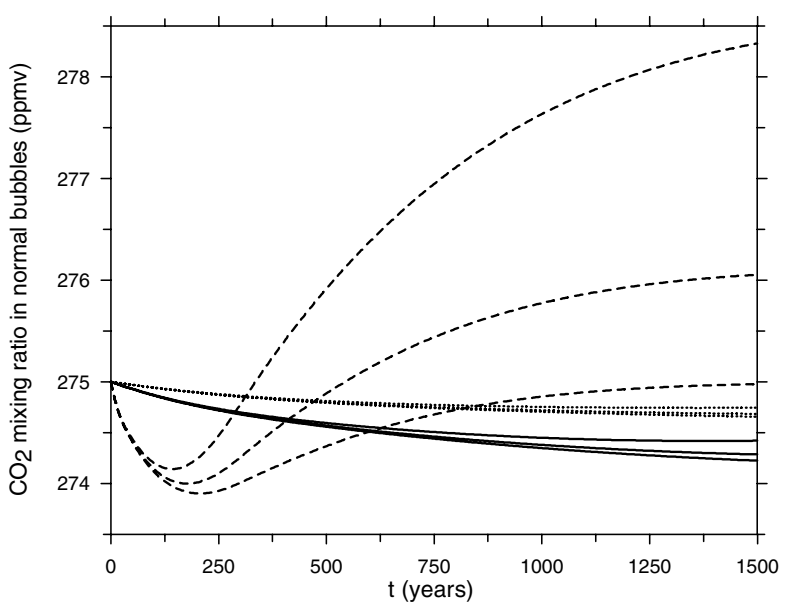

Fig 3. Calculation of the $\mathrm{CO}_{2}$ concentrations of air enclosed in normal bubbles with the boundary conditions explained in the text, $t=0$ is at close-off. For every site, three calculations were made with different initial $\mathrm{CO}_{2}$ concentrations in the microbubbles of 275, 500 and 1000 ppmv. The corresponding equilibrium concentrations (if all air from the microbubbles and normal bubbles is mixed up) are 275, 276.1 and 278.6 ppmv, respectively. Dashed curves: calculations for Law Dome DSS (mean temperature $-22{ }^{\circ} \mathrm{C}$ ). Full curves: calculations for DML $\left(-44.6{ }^{\circ} \mathrm{C}\right)$. Dotted curves: calculations for the South Pole $\left(-51^{\circ} \mathrm{C}\right)$.

range of $10 \%$ for the three cores. This result strongly depends on the assumptions about grain sizes at the surface of the firn zone.

Little is known about $\mathrm{CO}_{2}$ concentrations of air included in microbubbles. We therefore started our model with three different $\mathrm{CO}_{2}$ concentrations in microbubbles of 1000, 500 and 275 ppmv. The initial $\mathrm{CO}_{2}$ mixing ratio of normal bubbles is 275 ppmv. We assume that the composition of $\mathrm{O}_{2}$ and $\mathrm{N}_{2}$ is that of the atmosphere.

The assumptions for the calculation of this diffusion or permeation are given in the Appendix. The results for the evolution of the $\mathrm{CO}_{2}$ concentration in normal bubbles calculated for the sites of South Pole, DML and Law Dome are shown in Fig. 3. The concentration which would be measured, if the air of microbubbles and normal bubbles was mixed, are 278.6, 276.1 and 275 ppmv, respectively. However, these values are only reached after all gases from the microbubbles reach an equilibrium in their composition and pressure with normal bubbles by molecular diffusion. The results of the model show that the effect of diffusion through the ice matrix may influence the concentration in the normal bubbles by several ppmv. The partial pressure of $\mathrm{CO}_{2}$ in the normal bubbles first decreases because of the larger ratio of $\mathrm{N}_{2}$ and $\mathrm{O}_{2}$ diffusing into the normal bubbles due to larger permeation coefficients compared with $\mathrm{CO}_{2}$. Then, the partial pressure of $\mathrm{CO}_{2}$ increases up to the equilibrium concentration when the concentrations in normal bubbles and microbubbles approach equilibrium, which needs more than $1000 \mathrm{yr}$. The time response of the minimum and the trend in general strongly depends on the permeation coefficients and its temperature dependence, and also on the assumptions concerning bubble pressure. The results calculated for South Pole, DML and Law Dome show large differences, primarily due to the different temperatures of the sites. Therefore, we conclude that air dissolved in microbubbles cannot explain the distinct $\mathrm{CO}_{2}$ minimum observed in all records (and also in the Greenland records) at $\mathrm{AD} 1700$ which is of the order of about 5 ppmv and which is achieved on a timescale of just a few centuries and which, therefore, is clearly an atmospheric phenomenon.

\section{Conclusions}

Based on the good agreement of the general trend of the records from Law Dome and DML and also with a few values from the South Pole with very different ice characteristics, we conclude that the observed time evolution very likely describes the evolution of the atmospheric $\mathrm{CO}_{2}$ concentration. In particular, the increase between $\mathrm{AD} 1000$ and $\mathrm{AD} 1200$ and the distinct $\mathrm{CO}_{2}$ minimum between $\mathrm{AD} 1600$ and $\mathrm{AD} 1750$ is a robust feature which cannot be explained by diffusion of $\mathrm{CO}_{2}$ from microbubbles or by production of $\mathrm{CO}_{2}$ by chemical reactions. However, despite these considerations we cannot exclude any artefacts. No explanation for the observation of higher scatter of results in young compared with older ice has been found yet. Even if the general evolution of the atmospheric $\mathrm{CO}_{2}$ concentration of the past millennium is not in question, there remain open questions concerning the concentration differences of up to 4 ppmv in the trends of the three records in the first half of the last millennium.

\section{Acknowledgments}

This work is a contribution to the "European Project for Ice Coring in Antarctica“ (EPICA), a joint ESF (European Science Foundation)/EC scientific programme, funded by the European Commission and by national contributions from Belgium, Denmark, France, Germany, Italy, The Netherlands, Norway, Sweden, Switzerland and the United Kingdom. The measurements were supported by the Swiss NSF, University of Bern and the "Bundesamt für Energie". This is EPICA publication no 107.

\section{Appendix}

$\mathrm{CO}_{2}$ diffuses from microbubbles to normal bubbles through the ice matrix. A higher partial pressure surrounding a microbubble at close-off is caused by the higher $\mathrm{CO}_{2}$ concentration of the air (except for the calculations with the same initial concentrations for microbubbles and normal bubbles), but also because the pressure in microbubbles is slightly higher than in normal bubbles. At Vostok, it was observed that the pressure of microbubbles and normal bubbles converges with increasing depth and becomes identical below a depth of $500 \mathrm{~m}$ (Lipenkov, 2000). The flux of $\mathrm{CO}_{2}$ from microbubbles to normal bubbles is 
Table 2. Parameters constant with time

\begin{tabular}{lll}
\hline Symbol & \multicolumn{1}{c}{ Definition } & Value \\
\hline$n_{\mathrm{n}}$ & Density of normal bubbles & $480 \mathrm{~cm}^{-3}$ \\
$n_{\mathrm{a}}$ & Density of microbubbles & $120 \mathrm{~cm}^{-3}$ \\
$D_{\mathrm{N}_{2}}^{s 0}$ & Constant for diffusive permeation of $\mathrm{N}_{2}$ & $2.4 \times 10^{-9} \mathrm{~m}^{2} \mathrm{~s}^{-1} \mathrm{MPa}^{-1}$ \\
$D_{\mathrm{O}_{2}}^{s 0}$ & Constant for diffusive permeation of $\mathrm{O}_{2}$ & $2.4 \times 10^{-8} \mathrm{~m}^{2} \mathrm{~s}^{-1} \mathrm{MPa}^{-1}$ \\
$Q_{\mathrm{N}_{2}}^{s}$ & Activation energy of diffusive permeation of $\mathrm{N}_{2}$ & $55 \mathrm{~kJ} \mathrm{~mol}^{-1}$ \\
$Q_{\mathrm{O}_{2}}^{s}$ & Activation energy of diffusive permeation of $\mathrm{O}_{2}$ & $57 \mathrm{~kJ} \mathrm{~mol}^{-1}$ \\
$D_{g 0}$ & Constant for diffusion of $\mathrm{CO}_{2}$ & $1.8 \times 10^{-6} \mathrm{~m}^{2} \mathrm{~s}^{-1}$ \\
$E_{\mathrm{CO}_{2}}$ & Activation energy for diffusion of $\mathrm{CO}_{2}$ & $0.43 \mathrm{eV}$ \\
$C_{\mathrm{CO}_{2}}$ & Concentration of $\mathrm{CO}_{2}$ in ice matrix at $1 \mathrm{MPa}$ & $7.6 \times 10^{-9} \mathrm{MPa}^{-1}$ \\
\hline
\end{tabular}

Table 3. Parameters varying with time (in the last column the numerical values for $t=0$ are given).

\begin{tabular}{lll}
\hline Symbol & \multicolumn{1}{c}{ Definition } & Value \\
\hline$\overline{r_{\mathrm{a}}}$ & Mean radius of microbubbles & $0.07 \mathrm{~mm}^{\mathrm{a}}$ \\
$\overline{r_{\mathrm{n}}}$ & Mean radius of normal bubbles & $0.34 \mathrm{~mm}^{\mathrm{a}}$ \\
$\bar{Z}_{\mathrm{CO}_{2}}$ & Molar fraction of $\mathrm{CO}_{2}$ in normal bubble & $275 \mathrm{ppmv}$ \\
$\bar{Z}_{\mathrm{N}_{2}} / \bar{Z}_{\mathrm{O}_{2}}$ & $\mathrm{~N}_{2} / \mathrm{O}_{2}$ ratio in normal bubble & 3.71 \\
$\bar{Z}_{\mathrm{CO}_{2}}^{\mathrm{a}}$ & Mole fraction of $\mathrm{CO}_{2}$ in microbubbles & $275,500,1000 \mathrm{ppmv}$ \\
$\bar{Z}_{\mathrm{N}_{2}}^{\mathrm{a}} / \bar{Z}_{\mathrm{O}_{2}}^{\mathrm{a}}$ & $\mathrm{N}_{2} / \mathrm{O}_{2}$ ratio in microbubbles & 3.71 \\
$\left\langle P_{\mathrm{a}}\right\rangle$ & Mean pressure in microbubbles & $\left\langle P_{\mathrm{a}}\right\rangle=2.5 \times 10^{5} \mathrm{~Pa}+\Delta P_{\mathrm{a}} t^{\mathrm{b}}$ \\
$\left\langle P_{\mathrm{n}}\right\rangle$ & Mean pressure in normal bubbles & $\left\langle P_{\mathrm{n}}\right\rangle=10^{5} \mathrm{~Pa}+\Delta P_{\mathrm{n}} t^{\mathrm{b}}$ \\
\hline
\end{tabular}

${ }^{\text {a }}$ The mean radii are calculated assuming an air content of 99.5 and $0.5 \mathrm{ml}$ air STP per kg ice for normal bubbles and microbubbles, respectively and using the bubble densities and bubble pressures $n_{\mathrm{n}}, n_{\mathrm{a}}$ and $\left\langle P_{\mathrm{n}}\right\rangle,\left\langle P_{\mathrm{a}}\right\rangle$. The value in the table is calculated for the mean temperature of DML.

${ }^{\mathrm{b}} \Delta P_{\mathrm{a}}$ is estimated to be 628,748 and $5886 \mathrm{~Pa} \mathrm{yr}^{-1}$ for DML, South Pole and Law Dome respectively using the accumulation rates of the appropriate sites. $\Delta P_{\mathrm{n}}$ is 680,810 and $6376 \mathrm{~Pa} \mathrm{yr}^{-1}$ for DML, South Pole and Law Dome respectively. $\Delta P_{\mathrm{n}}$ is calculated so that at $200 \mathrm{~m}$ below close-off, both mean bubble pressures agree. At lower depths $\left\langle P_{\mathrm{n}}\right\rangle=\left\langle P_{\mathrm{a}}\right\rangle$ is valid.

calculated according to Ikeda-Fukazawa et al. (2001), who calculated a fractionation between $\mathrm{O}_{2}$ and $\mathrm{N}_{2}$ in ice from the Dome Fuji ice core due to a diffusion of $\mathrm{O}_{2}$ and $\mathrm{N}_{2}$ from microbubbles to normal bubbles. We also include the equations for $\mathrm{CO}_{2}$ with a higher concentration for microbubbles at enclosure depth and, different from their assumptions, we simplify the calculation by selecting a linear decreasing pressure difference against depth between microbubbles and normal bubbles which becomes equal at a depth of $200 \mathrm{~m}$ below close-off. The flux of the gas compound $m$ from microbubbles to normal bubbles is:

$q_{m}^{(\mathrm{a})}=4 \pi \gamma \overline{r_{\mathrm{a}}} D_{m} \frac{M_{m}}{M_{\mathrm{air}}}\left(\bar{Z}_{m}-\frac{\left\langle P_{\mathrm{a}}\right\rangle}{\left\langle P_{\mathrm{n}}\right\rangle} \bar{Z}_{m}^{\mathrm{a}}\right)$.

The flux from normal bubbles to microbubbles is:

$q_{m}^{(\mathrm{n})}=-4 \pi(1-\gamma) \overline{r_{\mathrm{n}}} D_{m} \frac{M_{m}}{M_{\text {air }}}\left(\bar{Z}_{m}-\frac{\left\langle P_{\mathrm{a}}\right\rangle}{\left\langle P_{\mathrm{n}}\right\rangle} \bar{Z}_{m}^{\mathrm{a}}\right)$,

where $M_{m}$ is the molar mass of the gas compound $m$ and $M_{\text {air }}$ is the molar mass of an average air molecule.
The averaging parameter $\gamma$, ranges from 0 to 1 and is given by:

$\frac{\gamma}{1-\gamma}=\frac{\overline{r_{\mathrm{n}}}}{\overline{r_{\mathrm{a}}}} \frac{n_{\mathrm{n}}}{1-n_{\mathrm{n}}}$

The mass balance of the gas compound $m$ is given by:

$\frac{\mathrm{d}\left(\left\langle P_{\mathrm{a}}\right\rangle \bar{Z}_{m}^{\mathrm{a}}\left\langle V_{\mathrm{a}}\right\rangle\right)}{\mathrm{d} t}=p_{\mathrm{iw}} q_{m}^{(\mathrm{a})}$,
$\frac{\mathrm{d}\left(\left\langle P_{\mathrm{n}}\right\rangle \bar{Z}_{m}\left\langle V_{\mathrm{n}}\right\rangle\right)}{\mathrm{d} t}=p_{\mathrm{iw}} q_{m}^{(\mathrm{n})}$,

where $\left\langle V_{\mathrm{a}}\right\rangle$ and $\left\langle V_{\mathrm{n}}\right\rangle$ are the mean volumes of microbubbles and normal bubbles. $p_{\mathrm{iw}}=z_{g} R \rho_{\mathrm{i}} T / M_{\mathrm{w}}$, where $z_{g}$ is the non-ideal compressibility coefficient, $\rho_{\mathrm{i}}$ is the density of ice, and $M_{\mathrm{w}}$ is the molar mass of water.

The diffusive permeation coefficient of molecule $m\left(m=\mathrm{N}_{2}\right.$, $\mathrm{O}_{2}$ ) in ice in equilibrium with air bubbles in $\mathrm{m}^{2} \mathrm{~s}^{-1}$ is given after 
Ikeda-Fukazawa et al. (2001):

$D_{m}=D_{m}^{s 0}\left\langle P_{\mathrm{n}}\right\rangle \exp \left(-\frac{Q_{m}^{s}}{R T}\right)$

A permeation coefficient for $\mathrm{CO}_{2}$ can be calculated with the values given in Hondoh (1996):

$D_{\mathrm{CO}_{2}}=C_{\mathrm{CO}_{2}}\left\langle P_{\mathrm{n}}\right\rangle D_{g 0} \exp \left(-\frac{E_{\mathrm{CO}_{2}}}{k T}\right)$.

The other symbols have the meanings and numerical values given in Tables 2 and 3. For example, the initial permeation coefficients $D_{\mathrm{O}_{2}}, D_{\mathrm{N}_{2}}$ and $D_{\mathrm{CO}_{2}}$ calculated with (A4) and (A5) using the parameters given in the tables and the mean temperature of DML are $2.3 \times 10^{-22}, 6.5 \times 10^{-23}$ and $4.5 \times 10^{-25} \mathrm{~m}^{2} \mathrm{~s}^{-1}$, respectively.

\section{References}

Anklin, M., Barnola, J.-M., Schwander, J., Stauffer, B. and Raynaud, D. 1995. Processes affecting the $\mathrm{CO}_{2}$ concentrations measured in Greenland ice. Tellus 47B, 461-470.

Barnola, J.-M. 1999. Status of the atmospheric $\mathrm{CO}_{2}$ reconstruction from ice core analyses. Tellus 51B, 151-155.

Barnola, J.-M., Anklin, M., Porcheron, J., Raynaud, D., Schwander, J. et al. $1995 . \mathrm{CO}_{2}$ evolution during the last millennium as recorded by Antarctic and Greenland ice. Tellus 47B, 264-272.

Barnola, J.-M., Pimienta, P., Raynaud, D. and Korotkevich, Y. S. 1991. $\mathrm{CO}_{2}$-climate relationship as deduced from the Vostok ice core: a reexamination based on new measurements and on a re-evaluation of the air dating. Tellus 43B, 83-90.

Etheridge, D. M., Steele, L. P., Langenfelds, R. L., Francey, R. J., Barnola, J.-M. and Morgan, V. I. 1996. Natural and anthropogenic changes in atmospheric $\mathrm{CO}_{2}$ over the last 1000 years from air in Antarctic ice and firn. J. Geophys. Res. 101, 4115-4128.

Fuhrer, K., Neftel, A., Anklin, M. and Maggi, V. 1993. Continuous measurements of hydrogen peroxide, formaldehyde, calcium and ammonium concentrations along the new GRIP ice core from Summit, Central Greenland. Atmos. Environ. 12, 1873-1880.

Gerber, S., Joos, F., Brügger, P., Stocker, T. F., Mann, M. E. et al. 2003. Constraining temperature variations over the last millennium by comparing simulated and observed atmospheric $\mathrm{CO}_{2}$. Clim. Dyn. 20, 281-299.

Gillet, R. W., van Ommen, T. D., Jackson, A. V. and Ayers, G. P. 2000. Formaldehyde and peroxide concentrations in Law Dome (Antarctica) firn and ice cores. J. Glaciol. 46, 15-19.

Gow, A. J. 1969. On the rates of growth of grains and crystals in South Polar firn. J. Glaciol. 8, 241-252.

Güllük, T., Slemr, F. and Stauffer, B. 1998. Simultaneous measurements of $\mathrm{CO}_{2}, \mathrm{CH}_{4}$, and $\mathrm{N}_{2} \mathrm{O}$ in air extracted by sublimation from Antarctica ice cores: confirmation of the data obtained using other extraction techniques. J. Geophys. Res. 103, 15 971-15978.

Hondoh, T. 1996. Clathrate hydrates in polar ice sheets. Proc. 2nd Int. Conf. on Natural Gas Hydrates 131-138.

Ikeda-Fukazawa, T., Hondoh, T., Fukumura, T., Fukazawa, H. and Mae, S. 2001. Variation in $\mathrm{N}_{2} / \mathrm{O}_{2}$ ratio of occluded air in Dome Fuji Antarctic ice. J. Geophys. Res. 106, 17 799-17810.
Indermühle, A., Stocker, T. F., Joos, F., Fischer, H., Smith, H. J. et al. 1999. Holocene carbon-cycle dynamics based on $\mathrm{CO}_{2}$ trapped in ice at Taylor Dome, Antarctica. Nature 398, 121-126.

Keeling, C. D. and Whorf, T. P. 2003. Atmospheric $\mathrm{CO}_{2}$ records from sites in the SIO air sampling network. In: Trends: A Compendium of Data on Global Change. Carbon Dioxide Information Analysis Center, Oak Ridge National Laboratory, US Department of Energy, Oak Ridge, TN.

Langway, C. C., Clausen, H. B. and Hammer, C. U. 1988. An interhemispheric volcanic time-marker in ice cores from Greenland and Antarctica. Ann. Glaciol. 10, 102-108.

Lipenkov, V. Y. 2000. Air bubbles and air-hydrate crystals in the Vostok ice core. In: ICSI Workshop on Physics of Ice-core Records (ed. T. Hondoh). Hokkaido University Press, Sapporo, 327-358.

Martinerie, P., Lipenkov, V. Y., Raynaud, D., Chappellaz, J. Barkov, N. I. et al. 1994. Air content paleo record in the Vostok ice core (Antarctica): a mixed record of climatic and glaciological parameters. J. Geophys. Res. 99, $10565-10576$.

Neftel, A., Jacob, P. and Klockow, D. 1984. Measurements of hydrogen peroxide in polar ice samples. Nature 311, 43-45.

Neftel, A., Moor, E., Oeschger, H. and Stauffer, B. 1985. Evidence from polar ice cores for the increase in atmospheric $\mathrm{CO}_{2}$ in the past two centuries. Nature 315, 45-47.

Siegenthaler, U., Friedli, H., Loetscher, H., Moor, E., Neftel, A. et al. 1988. Stable-isotope ratios and concentration of $\mathrm{CO}_{2}$ in air from polar ice cores. Ann. Glaciol. 10, 151-156.

Smith, H. J., Wahlen, M., Mastroianni, D., Taylor, K. C. and Mayewski, P. A. 1997. The $\mathrm{CO}_{2}$ concentration of air trapped in Greenland Ice Sheet Project 2 ice formed during periods of rapid climate change. J. Geophys. Res. 102, 26577-26582.

Sommer, B. 2000. Klima-Informationen von chemischen Spurenstoffkonzentrationen in polaren Eisbohrkernen. $\mathrm{PhD}$ Thesis. Physikalisches Institut, Universität Bern, Bern.

Souney, J. M., Mayewsky, P. A., Goodwin, I. D., Meeker, L. D., Morgan, V. et al. 2002. A 700-year record of atmospheric circulation developed from the Law Dome ice core, East Antarctica. J. Geophys. Res. 107, doi:10.1029/2002JD002104.

Spahni, R., Schwander, J., Flückiger, J., Stauffer, B., Chappellaz, J. et al. 2003. The attenuation of fast atmospheric $\mathrm{CH}_{4}$ variations recorded in polar ice cores. Geophys. Res. Let. 30, doi:10.1029/2003GL017093.

Stauffer, B. 1981. Mechanismen des Lufteinschlusses in natürlichem Eis. Z. Gletscherkunde Glazialgeol. 17, 17-56.

Stauffer, B. and Berner, W. 1978. $\mathrm{CO}_{2}$ in natural ice. J. Glaciol. 21, 291-300.

Stauffer, B., Flückiger, J., Monnin, E., Nakazawa, T. and Aoki, S. 2003. Discussion of the reliability of $\mathrm{CO}_{2}, \mathrm{CH}_{4}$ and $\mathrm{N}_{2} \mathrm{O}$ records from polar ice cores. In: International Symposium on the Dome Fuji Ice Core and Related Topics (eds. H. Shoji and O. Watanabe). National Institute of Polar Research, Tokyo, 139-152.

Stauffer, B., Flückiger, J., Monnin, E., Schwander, J., Barnola, J.-M. et al. 2002. Atmospheric $\mathrm{CO}_{2}, \mathrm{CH}_{4}$ and $\mathrm{N}_{2} \mathrm{O}$ records over the past 60,000 years based on the comparison of different polar ice cores. Ann. Glaciol. 35, 202-208.

Tschumi, J. and Stauffer, B. 2000. Reconstructing past atmospheric $\mathrm{CO}_{2}$ concentration based on ice-core analyses: open questions due to in situ production of $\mathrm{CO}_{2}$ in the ice. J. Glaciol. 46, 45-53. 